\title{
Effects of water level fluctuation and sediment-water nutrient exchange on phosphorus biogeochemistry in two coastal wetlands
}

\author{
Solange Duhamel ${ }^{1}$ - Géraldine Nogaro ${ }^{2,3}$ - Alan D. Steinman ${ }^{2}$
}

Received: 20 October 2014/Accepted: 14 March 2016/Published online: 22 March 2016

(C) Springer International Publishing 2016

\begin{abstract}
Freshwater coastal wetlands are sensitive to drying and wetting events (DWE), associated with water level fluctuations. Prior studies have shown that DWE influence sediment-water nutrient exchange, but the fate of these nutrients has received much less attention. To address this information gap, we investigated how microbial (i.e., bacteria and phytoplankton) structure and function respond to DWE-induced release of nutrients from the sediment of mesotrophic and eutrophic coastal wetlands. Our approach was three-fold: (1) sediment from each wetland was subjected to a desiccation (2 month) and re-wetting (2 days) period in the laboratory; (2) the overlying water column from the DWE was measured for nutrient concentration; and (3) we conducted a microbial response experiment using the water from either DWE experiment (containing the nutrients released during the DWE) or with added nutrients obtained from commercially available sources (but at similar concentrations to those released from the sediments), to test the effect of nutrient concentration and source on microbes inhabiting the water column and their role in the fate of the released nutrients, in particular phosphate $(\mathrm{Pi})$. In both coastal wetlands, the microbial community structure in the water column (absolute and
\end{abstract}

Solange Duhamel

sduhamel@1deo.columbia.edu

1 Division of Biology and Paleo Environment, Lamont-Doherty Earth Observatory, 61 Route 9 W, PO Box 1000, Palisades, NY 10964, USA

2 Annis Water Resources Institute, Grand Valley State University, Muskegon, MI 49441, USA

3 EDF R\&D, Laboratoire National d'Hydraulique et d'Environnement (LNHE), 6, quai Watier, 78400 Chatou, France relative abundance of different microbial groups) was modified by bacteria resuspended from the sediment after re-wetting. However, results from the microbial response experiments showed that the microbial communities did not grow following inputs of commercially available nutrients or release of sediment nutrients. In Pi amended treatments, Pi uptake rates increased but not enough to reduce Pi turnover time to values measured in the control. As a result, Pi concentration and turnover remained high. In coastal wetlands with limited hydrologic exchange, these elevated nutrients will accumulate and lead to further eutrophication. However, in open coastal wetlands, with substantial hydrologic exchange, advected nutrients may influence biological activity in the nearshore zone.

Keywords Water level fluctuations - Coastal wetlands . Phosphorus dynamics - Microbes - Stocks - Fluxes · Michigan

\section{Introduction}

Freshwater coastal wetlands help to control sediment transport, filter nutrients and contaminants, sequester carbon (C), and sustain biological diversity (Stern et al. 2007, Kayranli et al. 2010). They also provide the second highest economic value per hectare of the main biomes on Earth (after estuarine areas) for their ecosystem services (Costanza et al. 1997; De Groot 2012). However, these wetlands are at risk because of land use change, eutrophication, toxics, and habitat fragmentation (Vitousek et al. 1997; Smith et al. 1999; IPCC 2007). Freshwater coastal wetlands are also particularly sensitive to drying/wetting events (DWE) associated with water level fluctuations (WLF), given their ecotonal position at the land-water interface; 
hence, DWE can impact the ecosystem services provided by coastal wetlands (Sierszen et al. 2012).

Despite human interventions to modulate WLF via dams and control structures (cf. Wantzen et al. 2008), global circulation models predict the severity and frequency of droughts and episodic storm events will increase in the future (IPCC 2007; Cook et al. 2015). Extended wet periods induce reducing conditions due to oxygen consumption in the top layer of sediment; in contrast, prolonged drought can result in sediment exposure and oxidation (Sabater and Tockner 2010). These WLF-mediated redox conditions may influence nutrient flux at the water-sediment interface (Song et al. 2007; Steinman et al. 2012; Gilbert et al. 2014); mechanisms potentially involved in nutrient release include mineralization of lysed bacterial cells after desiccation (Sparling et al. 1985), anoxia-driven dissociation of phosphorus (P)-bound iron oxyhdroxides (Boström et al. 1982), and reduced nutrient binding capacity of increasingly crystalline sediments with exposure (Baldwin 1996). Nutrients released from the sediment can accumulate in the water column and stimulate algal growth (Cymbola et al. 2008; Orihel et al. 2015), resulting in an increase of particulate and dissolved organic matter (DOM) (Jensen 1984; Malej et al. 2003). Despite substantial societal implications, including impaired water quality, reduced ecotourism, and impacted fisheries, it is still unknown if these released nutrients are taken up by organisms, and if so, to what degree and by whom.

Lake sediments are considered as sinks of $\mathrm{P}$ and studies evaluating forms of $\mathrm{P}$ in lake sediments have shown its relatively high potential bioavailability (Zhou et al. 2001, Wang and Liang 2015). Previous studies demonstrated that relatively high $\mathrm{P}$ could be released from dried sediment after re-wetting (Steinman et al. 2012, 2014; Gilbert et al. 2014). Thus $P$ released from the sediment has the potential to increase $\mathrm{P}$ availability in the water column. Although phosphate $(\mathrm{Pi})$ is generally considered to be the favored form of $\mathrm{P}$ for microbial uptake, bacteria and phytoplankton use dissolved organic $\mathrm{P}$ (DOP), regardless of whether or not Pi is limiting (Karl and Björkman 2002; Duhamel et al. 2011). DOP must be enzymatically hydrolyzed before it can be taken up by microbes (Cembella et al. 1984; Ammerman and Azam 1985).

Our main objective was to assess the effects of nutrient source (SEDN [sediment-derived nutrients]: nutrients released from meso- and eutrophic freshwater coastal wetland sediments exposed to a drying and wetting event vs. CAN: commercially available nutrients) on microbial function and structure. Our approach was three-fold: (1) sediment cores from one mesotrophic and two eutrophic wetlands were subjected to a desiccation ( 2 months) and rewetting (2 days) period in the laboratory; (2) the overlying water column from this DWE was then measured for nutrient concentration; and (3) a microbial response experiment was conducted using the water from either the desiccation/re-wetting experiment (containing the nutrients released during the DWE) or with similar concentrations of inorganic nutrients obtained from commercially available sources. We hypothesized that: (1) nutrient release from sediments would be greater in the more eutrophic wetland; (2) an increase in nutrient concentration in the water column would stimulate bacteria and phytoplankton growth, and alter microbial community structure by supporting populations adapted to higher nutrient concentrations; and (3) SEDN, derived from sediments, would stimulate greater microbial $\mathrm{P}$ uptake and growth than CAN because of greater concentrations of DOP.

\section{Materials and methods}

\section{Sampling location}

Sediment cores were collected from two freshwater coastal wetlands along the eastern shore of Lake Michigan (Fig. 1): Muskegon Lake (hereafter Muskegon, 43.246; -86.334, mesotrophic) and a muck field associated with Bear Lake (hereafter Bear, 43.266; -86.264, hypereutrophic) in the fall 2013. Briefly, Muskegon is a drowned river mouth lake that connects to Lake Michigan through a navigation channel. We sampled the sediment from a wetland along the lake's north shore, which has received less anthropogenic impact than other parts of the lake (Steinman et al. 2008). The Bear muck field is a former natural wetland that was converted to celery production in the early-20th century, but taken out of production in the 1990s and allowed to reflood. It is located immediately upstream of Bear Lake, which connects to Muskegon Lake through a navigation channel (Fig. 1).

\section{Desiccation/re-wetting experimental setup}

Fourteen sediment cores $(60 \mathrm{~cm}$ height, $7 \mathrm{~cm}$ internal diameter) were collected from each site at $0.25 \mathrm{~m}$ below the water surface and transported to the laboratory. We selected this depth because it falls well within the 20-year range of WLF in Lake Michigan $(\sim 1.5 \mathrm{~m}$; Gronewold et al. 2013) and those predicted from global change in the 21 st century ( $\sim 2 \mathrm{~m}$; IUGLS 2012). Water levels in the sediment cores were experimentally manipulated following the protocol described in Steinman et al. (2012). Briefly, overlying water was gently drawn off the sediment cores using a peristaltic pump and analyzed for nutrient concentration. The sediment cores were placed uncapped in a walk-in growth chamber set to the ambient sampling conditions: water temperature of $11^{\circ} \mathrm{C}$ and a $12 / 12 \mathrm{~h}$ 


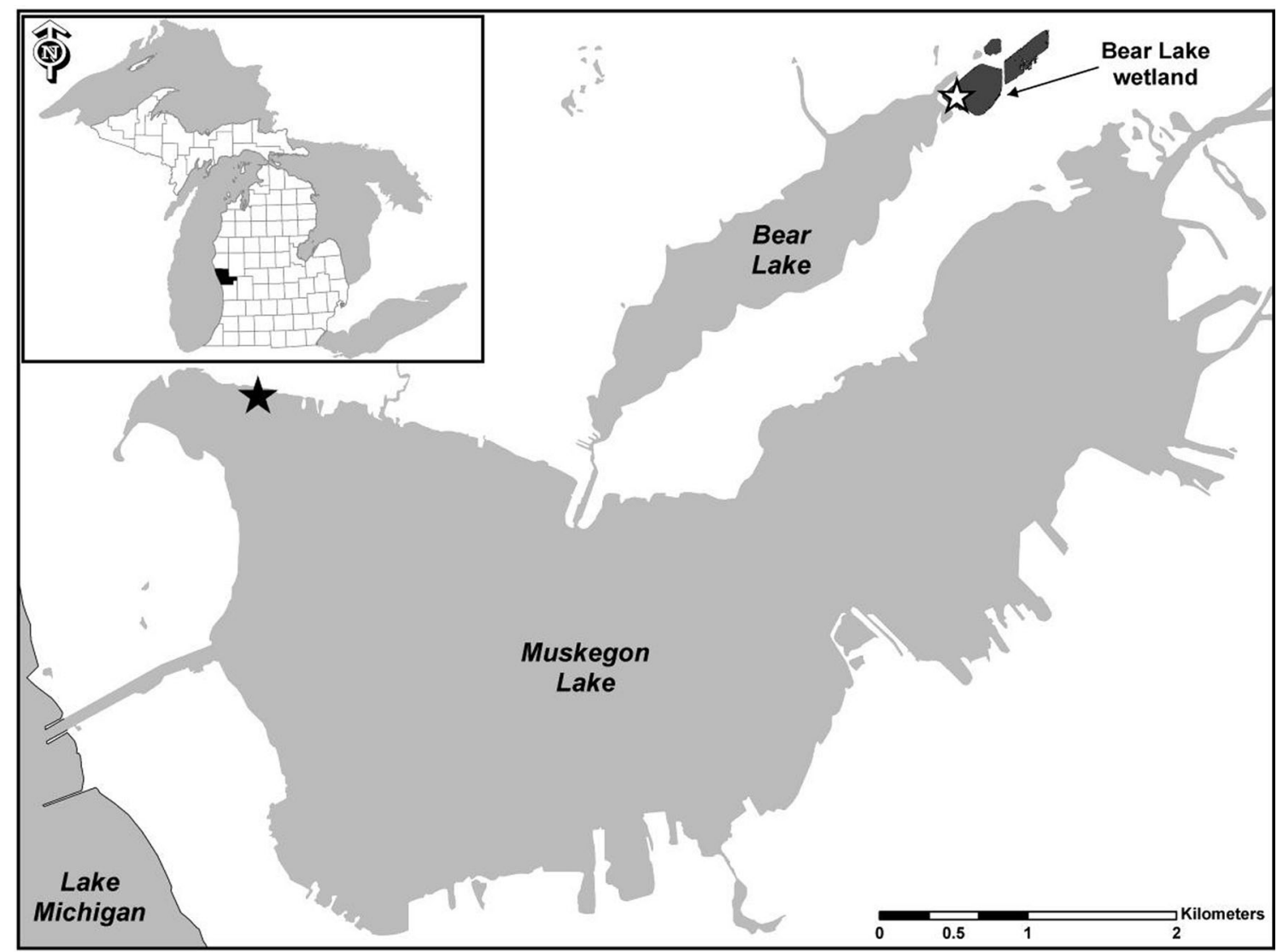

Fig. 1 Location of Muskegon Lake and Bear Lake wetland sampling sites in Michigan, USA. Stars indicate the sediment core sites. Inset location of Muskegon County, the site of sampling (top left rectangle) within Laurentian Great Lakes region

light/dark photoperiod, and allowed to dry naturally. After 2 months of desiccation (Steinman et al. 2012), water to be used for re-wetting and incubation experiments was collected from both sampling sites and gently filtered through $63 \mu \mathrm{m}$ Nitex ${ }^{\circledR}$ to remove large grazers. Subsamples were analyzed for nutrient content as described below. The desiccated sediment cores were re-wetted using 500-ml of filtered surface water from the corresponding site. A subsample of the supernatant water was gently drawn off as described above after $24 \mathrm{~h}$ of re-wetting (to measure water column nutrient concentration; see below). The remaining supernatant water was gently drawn off after $48 \mathrm{~h}$, filtered using $63 \mu \mathrm{m} \mathrm{Nitex}{ }^{\circledR}$, and homogenized for use in the microbial response experiment (see below).

\section{Microbial response experimental setup}

The main goals of the microbial response experiment were to: (1) measure microbial utilization of nutrient released from the sediment in the water column after a DWE and (2) determine the effects of such a nutrient increase (i.e., increased eutrophication), using different nutrient sources, on the water column microbial community structure (i.e., the different kinds of organisms and their abundances) and function. The microbial response experiments included three treatments (Fig. 2): (1) Control (Ctr), which consisted solely of a surface water sample (SW) collected from both sampling sites and filtered $\left(63 \mu \mathrm{m} \mathrm{Nitex}{ }^{\circledR}\right)$ under low rate using a peristaltic pump, (2) Sediment-derived Nutrients (SEDN), which consisted of the filtered SW plus supernatant from the re-wetted sediment cores (from the desiccation/re-wetting experiment); and (3) Commercially Available Nutrients (CAN), which consisted of the filtered $\mathrm{SW}$ plus commercial Pi and $\mathrm{NH}_{4}{ }^{+}$, added to result in a final inorganic nutrient concentration equivalent to that in the SEDN treatment, based on analyzed subsamples. Our goal was to maximize the potential microbial response to WLFinduced nutrient release from the sediment. Thus, the supernatants of each sediment cores from the desiccation/ re-wetting experiment were pooled before being equally divided among the SEDN treatment incubation bottles, corresponding to a volume of $380-\mathrm{mL}$ per $2-\mathrm{L}$ bottle (Fig. 2).

The SEDN treatment was used to test the effect of WLFinduced nutrient release from the rewetted sediment cores on nutrient processing by the microbial community in the 


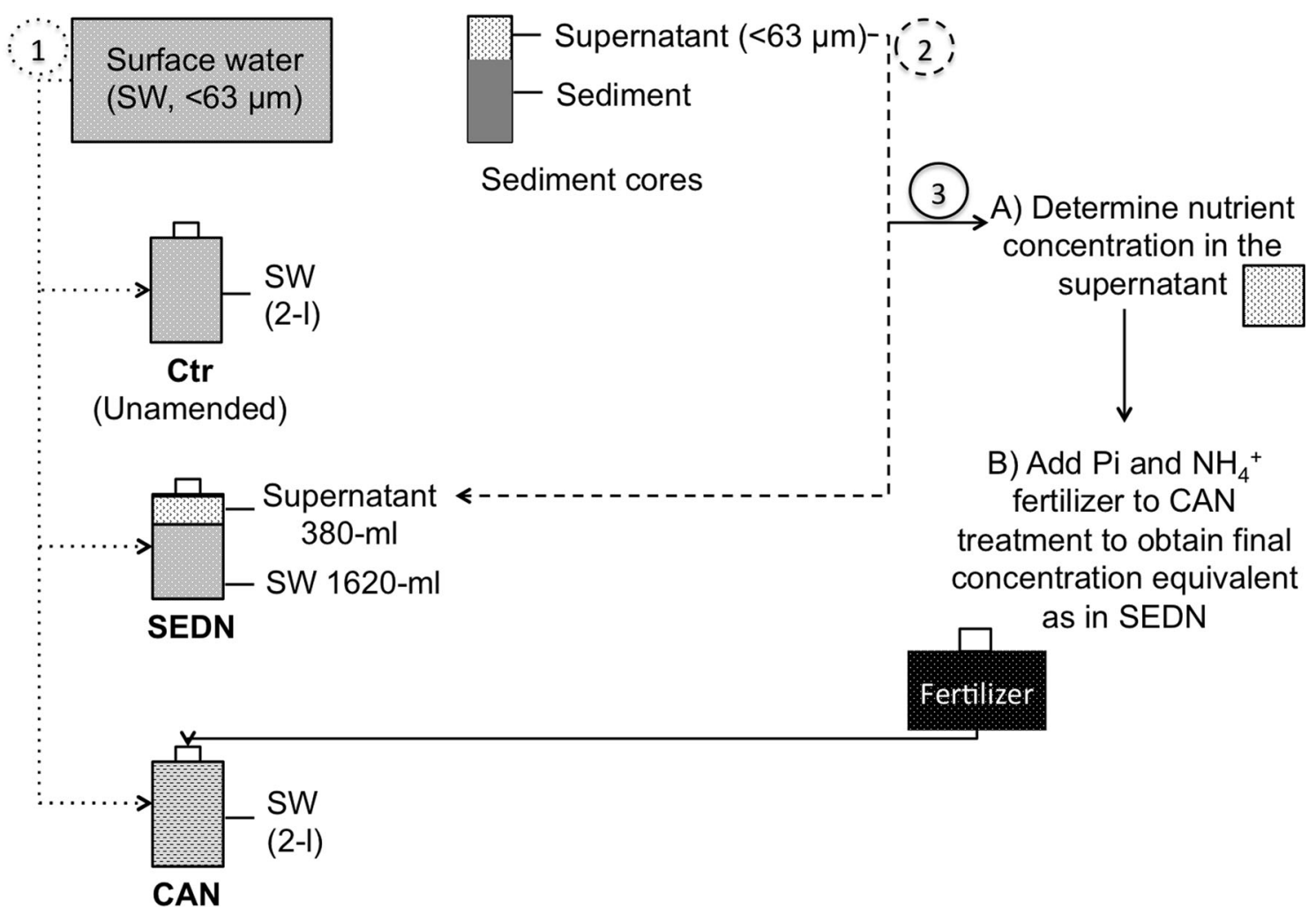

Fig. 2 Schematic of the experimental set-up for the microbial response experiment. The microbial response experiment included three treatments: Control $(\mathrm{Ctr})=$ unamended surface water sample $(\mathrm{SW})$, Mixed $(\mathrm{SEDN})=\mathrm{SW}+$ re-wetted sediment core supernatant, and Nutrient-amended $(\mathrm{CAN})=\mathrm{SW}+\mathrm{Pi}+\mathrm{NH}_{4}{ }^{+}$to a final concentration estimated to be equivalent to that in SEDN. The different treatments were prepared as follows, with numbers corresponding to circled numbers in figure: (1) dotted arrows SW filtered onto $63-\mu \mathrm{m}$ mesh was distributed into 2-1 bottles (2000-ml for Ctr and CAN and

water column. The CAN treatment was used to compare the results from SEDN, by teasing out the effect of inorganic nutrient fertilization from other factors (in particular, DOP availability) that may be released from the sediment. Results from the SEDN and CAN treatments were compared to those of a control treatment (Ctr, unamended SW).

For each site, triplicate 2-1 bottles were prepared for each treatment and sampling day (T0, T3, T6; i.e., after 0,3 and 6 days of incubation, respectively), totaling 27 bottles. The sampling frequency provided sufficient time to detect changes in microbial structure and function but was not so frequent as to create logistical sampling challenges, and also encompassed natural hydraulic residence times of protected coastal wetlands in the Great Lakes (Trebitz et al. 2002).

As noted above, nutrient composition and concentration were measured after sediment cores had been rewetted for $24 \mathrm{~h}$, even though the re-wetting lasted for $48 \mathrm{~h}$. This shorter sampling period gave us $24 \mathrm{~h}$ to quantify the 1620-ml for SEDN), (2) dashed arrow the sediment core supernatant was then added to the SEDN treatment bottles (380-ml per bottle) and (3) solid arrows an aliquot was analyzed for nutrient concentration, which was used to determine the amount of commercially available $\mathrm{Pi}$ and $\mathrm{NH}_{4}{ }^{+}$to add to the CAN treatment bottles in order to reach final concentrations equivalent to the SEDN treatment. For each site, triplicate $2-1$ bottles were prepared for each treatment and sampling day (T0, T3, T6; i.e., after 0,3 and 6 days of incubation), totaling 27 bottles

concentrations of released $\mathrm{Pi}$ and $\mathrm{NH}_{4}{ }^{+}$in the overlying water, which we used to determine the appropriate nutrient concentrations for the CAN treatment. We assumed the change in absolute concentrations would be minimal between days 1 and 2, especially compared to longer time frames (Steinman et al. 2014). Hence, we had three nutrient treatments: Ctr (surface water from the wetland); SEDN (surface water plus supernatant from the rewetted sediment); and CAN (surface water plus commercially available nutrients at concentrations equivalent to those in SEDN; Fig. 2). The actual concentrations for the SEDN treatment involved the addition of 1.65 and $0.00 \mu \mathrm{mol} \mathrm{l^{-1 }}$ of $\mathrm{Pi}$, and 22.82 and $5.34 \mu \mathrm{mol} \mathrm{l}^{-1}$ of $\mathrm{NH}_{4}{ }^{+}$, in Muskegon and Bear surface samples, respectively. The CAN treatments consisted of adding $\mathrm{Pi}$ as $\mathrm{KH}_{2} \mathrm{PO}_{4}$ and $\mathrm{NH}_{4}$ as $\mathrm{NH}_{4} \mathrm{Cl}$ to $2-1$ of SW from each site, to match the concentrations of those in the SEDN treatment (Fig. 2). The bottles were incubated in the same way as the sediment cores. Three bottles from each treatment were sacrificed on 
each sampling date and analyzed for phosphate (Pi), ammonium $\left(\mathrm{NH}_{4}{ }^{+}\right)$, picoplankton cell abundance, and uptake of Pi and ATP.

\section{Sample analyses}

\section{Chemical analyses}

Sediment organic matter $(\mathrm{OM})$ content and particle size distribution were determined in the top $5 \mathrm{~cm}$ of the sediment cores after drying/re-wetting and removing the supernatant used in the SEDN treatment. OM was measured as loss upon ignition (LOI) at $550{ }^{\circ} \mathrm{C}$ for $1 \mathrm{~h}$ (APHA 2005); we report the data as sediment \% OM. Moisture content was not measured before re-wetting in order to avoid disturbing the cores but after a similar desiccation period. Steinman et al. (2014) found 6 to $15 \%$ moisture left in sediments that had \% OM (i.e., 0-5\%) similar to those in our study. Particle sizes were determined by drysieving $(2000,1000,500,250,125$, and $63 \mu \mathrm{m})$. Pi and $\mathrm{NH}_{4}{ }^{+}$concentrations were determined following standard colorimetric methods (Weatherburn 1967; USEPA 1983) on filtered samples $(0.45-\mu \mathrm{m})$. Total phosphorus (TP) and total dissolved phosphorus (TDP) concentrations in surface water samples (after acid-persulfate digestion) were determined according to the ascorbic acid method (USEPA $1983)$ on whole and filtered samples $(0.45-\mu \mathrm{m})$, respectively. DOP concentrations were calculated as the difference between TDP and Pi. DOP represented a small fraction of TDP in both wetlands. Taking the entire dataset into account, DOP was $11 \pm 12 \%$ of TDP. Considering the errors associated with measuring TDP and SRP, we did not feel confident that our DOP measurements were consistently different from zero and are not reported here.

\section{Picoplankton cell abundance}

The microbial community structure was assessed by flow cytometry, which allows the identification and enumeration of groups of similar cells (Aghaeepour et al. 2011). Flow cytometry samples (2-ml) were fixed in a final concentration of $0.25 \%$ paraformaldehyde for $10 \mathrm{~min}$, flash-frozen in liquid nitrogen, and stored at $-80{ }^{\circ} \mathrm{C}$ until analysis. Picoplankton cell groups and their abundances were identified using a $\mathrm{BD}^{\circledR}$ Influx flow cytometer. Flow cytometry data were analyzed using FCS Express Pro (De Novo Software). Pigmented groups (Synechococcus-like, small and large phytoplankton) were enumerated in unstained samples using their natural chlorophyll fluorescence and forward scatter signatures. The high phycoerythrin signal in the Synechococcus-like cell population was used to distinguish this group from two phytoplankton groups that were discriminated based on their size difference by forward scattering. To discriminate non-pigmented picoplankton (hereafter, bacteria), a $1-\mathrm{ml}$ aliquot was stained with SYBR green I (SG; $0.01 \%$ final concentration). Four groups of SG cell populations could be distinguished based on their green fluorescence and forward scattering: S1, S2, S3, and S4.

\section{Phosphorus uptake}

Pi uptake rates were determined using ${ }^{33} \mathrm{Pi}$ (as $\mathrm{H}_{3}^{33} \mathrm{PO}_{4}$, $>99 \%$, Perkin Elmer, NEZ080, 5.76 $\mathrm{TBq} \mathrm{mg}^{-1}$ ). Samples were incubated for $\sim 4 \mathrm{~h}$ in 50-ml polycarbonate tubes in an incubator set at in situ water temperature. After incubation, a duplicate 5-ml sample was transferred in a cryotube, fixed in a final concentration of $0.25 \%$ paraformaldehyde for $10 \mathrm{~min}$, and flash frozen in liquid nitrogen and stored at $-80{ }^{\circ} \mathrm{C}$ until flow cytometry sorting (see below). Then 2-ml samples were filtered separately onto $1.2 \mu \mathrm{m}$ (i.e., uptake by microorganisms dominated by phytoplankton-typically $>95 \%$ of the bacteria pass through $1.2 \mu \mathrm{m}$ pore-size filters, Biddanda et al. 2001) and $0.2 \mu \mathrm{m}$ (i.e., total uptake by the whole microbial community) polycarbonate filters at low pressure $(<0.6$ bars $)$. For whole water total radioactivity, a $20-\mu$ sample was collected from each incubation tube. Samples for total activity and filters were transferred into $6.5 \mathrm{ml}$ HDPE scintillation vials. An aliquot of 4-ml of scintillation cocktail (Ultima Gold ${ }^{\mathrm{TM}}$ LLT, Perkin Elmer) was added to the scintillation vials, and samples were counted on a Beckman LS6500. The linear relationship of Pi uptake increase with incubation time was checked regularly by subsampling four times over the course of an experiment and determining particulate activity. The Pi uptake kinetic parameters in the initial surface sample were evaluated using ${ }^{33} \mathrm{Pi}$ incubations amended with increasing Pi concentrations ranging from 0 to $5 \mu \mathrm{mol} 1^{-1}$.

Adenosine $5^{\prime}$-triphosphate (ATP) was used as the model substrate to evaluate DOP assimilation by microbes. Unlike other substrates, its $5^{\prime}$-nucleotidase activity is not inhibited by Pi concentration (Ammerman and Azam 1985). ATP uptake rates were determined using ${ }^{33} \mathrm{P}-\mathrm{ATP}$ (as $\left[\gamma-{ }^{33} \mathrm{P}\right]$ adenosine-5' $5^{\prime}$-triphosphate, $>95 \%$, Perkin Elmer, $\mathrm{NEG} 302 \mathrm{H}, 111 \mathrm{TBq} \mathrm{mmol}^{-1}$ ). Samples were incubated as described for Pi uptake rates. After incubation, a duplicate 5-ml sample was transferred in a cryotube, fixed and preserved as described above for flow cytometry sorting. Then 2-ml samples were filtered separately onto 1.2 and $0.2 \mu \mathrm{m}$ polycarbonate filters $(<0.6$ bars $)$. The filtrate was collected in a separate set of tubes to determine ATP hydrolysis (see below). Filters were rinsed 3 times with $<0.2 \mu \mathrm{m}$ filtered sample from the same sampling location. The tubes containing the filtrates to determine ATP hydrolysis were removed prior to rinsing the filters. Samples for total 
activity (20- $\mu$ l sample) and filters were assayed as described above.

\section{Microbial group specific P uptake}

Microbial groups from T0 and T6 samples were sorted on a BD Influx flow cytometer using the same discrimination parameters as for cell counts (Duhamel et al. 2012, 2014). Only bacteria (SG cell populations) were sorted. It was necessary to fix and preserve samples until the flow cytometric analyses could be completed. Although previous studies have shown that fixing samples prior to sorting may lead to radioactivity leakage from the cells (Zubkov et al. 2007; Talarmin et al. 2011), the differences in leakage among microbes would be similar and our conclusions, which are based on relative not absolute changes, should be unaffected (Casey et al. 2009; Michelou et al. 2011). Fluorescent microspheres $(1-\mu \mathrm{m}$ diameter, Fluoresbrite, Polysciences) were added to each sample and sorted at the same time as the microbial groups into separate vials, in order to determine radioactivity due to substrate carry over in sorted droplets (Björkman et al. 2012). Then, $4 \mathrm{ml}$ of liquid scintillation cocktail was added and samples were counted for radioactivity. The background activity $(\mathrm{Bq}$ bead $^{-1}$ ) was subtracted from the sample activity (Bq cell $^{-1}$ ). Radioactivity was undetectable in cell populations sorted from the negative controls (i.e., sample fixed with $0.2 \%$ paraformaldehyde $15 \mathrm{~min}$ prior to introduction of radioactive isotope) at $\mathrm{T} 0$ and was not further considered in data analysis.

\section{Uptake of Pi regenerated by ATP hydrolysis}

This assay is based on hydrolysis of ${ }^{33} \mathrm{P}$-labeled Pi from $\left[\gamma-{ }^{33} \mathrm{P}\right] \mathrm{ATP}$ and measures both release of ${ }^{33} \mathrm{Pi}$ and uptake of released ${ }^{33} \mathrm{Pi}$ (Ammerman and Azam 1985, 1991; Ammerman 1993). One $\mathrm{ml}$ of the filtrate from the sizefractionated samples used to measure ATP uptake (see above) was inoculated with $1-\mathrm{ml}$ of an activated charcoal slurry at $20 \mathrm{mg} \mathrm{ml}^{-1}$ in $0.03 \mathrm{~N} \mathrm{H}_{2} \mathrm{SO}_{4}$ to bind excess $\left[\gamma_{-}{ }^{33}\right.$ P]ATP (Ammerman and Azam 1991). The charcoalcontaining filtrates were filtered a second time using 0.45 $\mu \mathrm{m}$ filters (Millipore HA) in order to retain the excess $\left[\gamma-{ }^{33} \mathrm{P}\right] \mathrm{ATP}$. One $\mathrm{ml}$ of this filtrate containing ${ }^{33} \mathrm{Pi}$ released from $\left[\gamma_{-}{ }^{33} \mathrm{P}\right] \mathrm{ATP}$ hydrolysis was then counted as described above. Killed blank samples also were prepared to check that the auto-hydrolysis of ATP was negligible.

\section{Calculation and statistical analysis}

The Pi and ATP turnover times (TT, d) and Pi uptake rates $\left(\right.$ nmol 1 $\left.{ }^{-1} \mathrm{~d}^{-1}\right)$ were calculated as follows: $\mathrm{TT}=\mathrm{R}_{\mathrm{T}} / \mathrm{R}_{\mathrm{F}}$ and uptake rate $=\mathrm{Pi} / \mathrm{TT}$, where $\mathrm{R}_{\mathrm{T}}\left(\mathrm{Bq}^{-1}\right)$ is the total tracer added, $\mathrm{R}_{\mathrm{F}}\left(\mathrm{Bq} \mathrm{l}^{-1} \mathrm{~d}^{-1}\right)$ is the radioactivity on the filter or in the sorted cell population, and $\mathrm{Pi}$ is the $\mathrm{Pi}$ concentration $\left(\mathrm{nmol} \mathrm{l}^{-1}\right)$. Pi and ATP turnover rates were calculated as $1 /$ TT $\left(\mathrm{d}^{-1}\right)$. P turnover time based on the removal of radiolabeled $\mathrm{P}$ substrate from solution is an index of P demand by osmotrophs (Lean and Nalewajko 1979). Short TT values mean high demand relative to supply, whereas long TT values suggest that some other factor is limiting microbial growth.

ATP hydrolysis $\left(\% \mathrm{~h}^{-1}\right)$, uptake of Pi released by ATP hydrolysis (i.e., $5^{\prime}$-nucleotidase activity, $\% \mathrm{~h}^{-1}$ ), and percent uptake of Pi regenerated by $5^{\prime}$-nucleotidase (\%) were calculated as follows: ATP hydrolysis $=100 \times\left[\left(\mathrm{R}_{\mathrm{f}}+\mathrm{R}_{\mathrm{fe}}\right) / \mathrm{R}_{\mathrm{t}}\right] / t ; \quad 5^{\prime}$-nucleotidase activity $=100 \times\left(\mathrm{R}_{\mathrm{f}} / \mathrm{R}_{\mathrm{t}}\right) / \mathrm{t}$; percent uptake of Pi regenerated by $5^{\prime}$-nucleotidase $=100 \times$ (uptake of Pi released by ATP hydrolysis/ATP hydrolysis), using the radioactivity on the filter, in the filtrate after charcoal extraction or in the total sample $\left(\mathrm{R}_{\mathrm{f}}, \mathrm{R}_{\mathrm{fe}}, \mathrm{R}_{\mathrm{t}}\right.$, respectively, $\left.\mathrm{dpm} \mathrm{ml}^{-1}\right)$ and $\mathrm{t}=$ the incubation time.

Results are reported as mean \pm standard deviation (SD; number of observations: $\mathrm{n}$ ). For each site, variables ( $\mathrm{Pi}$ and $\mathrm{NH}_{4}{ }^{+}$concentrations, bacterial and phytoplankton abundances, Pi turnover time, ATP turnover time, Pi uptake, and Pi uptake regenerated by $5^{\prime}$-nucleotidase) measured in the microbial response experiment were tested using a twoway analysis of variance (ANOVA) with treatment (i.e., Ctr, SEDN, and CAN) and time (T0, T3, and T6) as the main effects. Time was considered as a main factor instead of a repeated factor since different sets of bottles were used at each sampling time. Tukey post hoc tests were used in cases of significant ANOVA results to determine differences among treatments and time. When necessary, data were log-transformed before statistical analysis to meet the assumption of homoscedasticity and normality. Statistical analyses were performed using $\mathrm{R}$ software (R Core Team 2014).

\section{Results}

\section{Desiccation/re-wetting experiment}

\section{Sediment analyses}

There was no significant difference between the sediment size distributions in Muskegon and Bear $(p=0.975)$. At both sites, $>60 \%$ of the sediment was recovered in the 250-499 $\mu \mathrm{m}$ size fraction (data not shown). The organic matter content of the sediment was low at each location, but was significantly lower in Muskegon than in Bear sediments $(0.63 \pm 0.19 \%$ vs. $2.40 \pm 1.42 \%$, respectively, Fig. 3). Variability among the 14 sediment cores 
Fig. 3 Organic matter in the sediment $(\%)$ vs. concentration of ammonium $\left(\mathrm{NH}_{4}^{+}, \mathrm{mg} \mathrm{l}^{-1}\right.$, a) or total phosphorus (TP, $\mathrm{mg} \mathrm{l}^{-1}$, b) released from the sediment after re-wetting, for Bear (circles) and Muskegon (crosses)
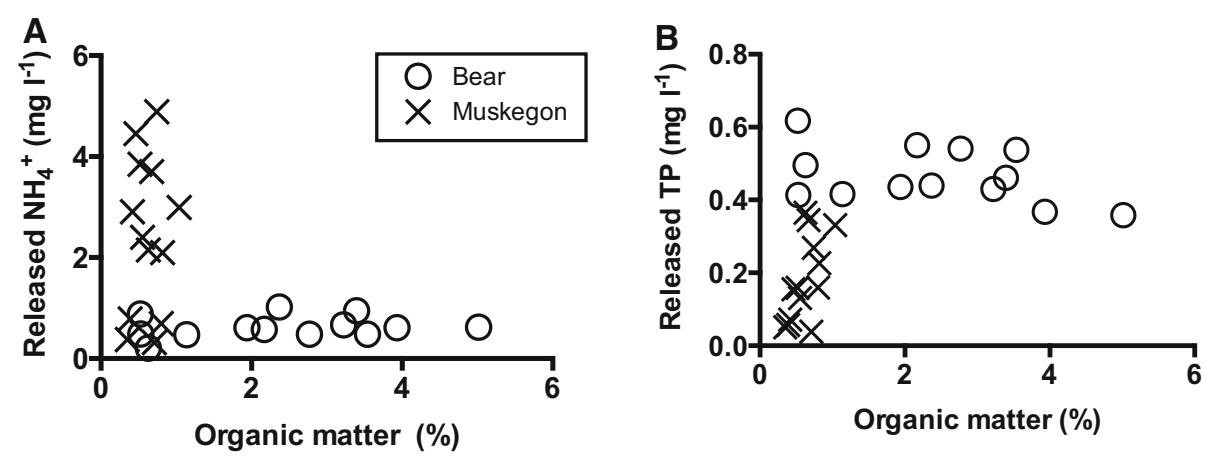

was higher for Bear than for Muskegon (coefficient of variation $=59 \%$ vs. $31 \%$, respectively). $\mathrm{NH}_{4}{ }^{+}$and TP concentrations released from sediment cores were not significantly correlated with organic matter content $\left(\mathrm{r}^{2}<0.5\right)$, although it is clear that TP release patterns were very different between the two wetlands (Fig. 3).

Nutrient concentration in the water column and releases from the sediment cores

Ambient Pi concentrations in surface waters of Muskegon and Bear were moderately and extremely high, respectively (Table 1: day 0 control treatment). Ambient $\mathrm{NH}_{4}{ }^{+}$concentrations also were relatively high in Muskegon and Bear surface waters, with a $\mathrm{NH}_{4}{ }^{+}$to Pi molar ratio of $159 \pm 0.1$ and $2.5 \pm 0.2$, respectively.

Nutrient release to the water column from the sediment core that was sacrificed after a 24-h re-wetting was $8.7 \pm 0.0 \mu \mathrm{mol} 1^{-1}$ of Pi and $120 \pm 1 \mu \mathrm{mol} \mathrm{l}^{-1}$ of $\mathrm{NH}_{4}{ }^{+}$ in Muskegon, whereas there was no net release of $\mathrm{Pi}$ and

Table 1 Mean \pm 1 SD $(n=3)$ of dissolved inorganic phosphate (Pi) and ammonium $\left(\mathrm{NH}_{4}{ }^{+}\right)$in the control $(\mathrm{Ctr})$, mixed (SEDN) and nutrient amended (CAN) treatments

\begin{tabular}{|c|c|c|c|c|}
\hline & \multicolumn{2}{|l|}{ Muskegon } & \multicolumn{2}{|l|}{ Bear } \\
\hline & $\mathrm{Pi}$ & $\mathrm{NH}_{4}^{+}$ & $\mathrm{Pi}$ & $\mathrm{NH}_{4}^{+}$ \\
\hline \multicolumn{5}{|l|}{$\mathrm{Ctr}$} \\
\hline T0 & $0.43 \pm 0.03$ & $69 \pm 3$ & $33 \pm 6$ & $82 \pm 3$ \\
\hline T3 & $1.01 \pm 0.00$ & $69 \pm 3$ & $33 \pm 2$ & $87 \pm 5$ \\
\hline T6 & $1.08 \pm 0.06$ & $61 \pm 12$ & $40 \pm 1$ & $78 \pm 7$ \\
\hline \multicolumn{5}{|c|}{ SEDN } \\
\hline T0 & $1.69 \pm 0.11$ & $310 \pm 3$ & $36 \pm 1$ & $127 \pm 3$ \\
\hline $\mathrm{T} 3$ & $2.28 \pm 0.40$ & $341 \pm 5$ & $35 \pm 2$ & $154 \pm 5$ \\
\hline T6 & $2.67 \pm 0.14$ & $336 \pm 16$ & $38 \pm 0$ & $160 \pm 5$ \\
\hline \multicolumn{5}{|l|}{ CAN } \\
\hline T0 & $2.26 \pm 0.08$ & $304 \pm 5$ & $37 \pm 0$ & $124 \pm 7$ \\
\hline T3 & $2.35 \pm 0.14$ & $258 \pm 5$ & $38 \pm 3$ & $131 \pm 5$ \\
\hline T6 & $2.47 \pm 0.31$ & $284 \pm 15$ & $38 \pm 2$ & $133 \pm 12$ \\
\hline
\end{tabular}

All values are in $\mu \mathrm{mol} 1^{-1}$ only $28 \pm 1 \mu \mathrm{mol} \mathrm{l}^{-1}$ of $\mathrm{NH}_{4}{ }^{+}$from Bear sediment. These concentrations were used to calculate the amount of $\mathrm{NH}_{4}{ }^{+}$ and $\mathrm{Pi}$ to add in the CAN treatments to mimic the concentrations present in the SEDN treatment. The release of nutrients from the sediment corresponded to a $3.9 \pm 0.1$ and 0 -fold increase in $\mathrm{Pi}$, and $4.5 \pm 0.0$ and $1.5 \pm 0.0$-fold increase in $\mathrm{NH}_{4}$, in the water column of Muskegon and Bear, respectively.

\section{Microbial response experiment}

\section{Nutrient concentrations}

During the course of the microbial response experiment, Pi concentration significantly increased in the control and SEDN treatment between T0 and T3 in Muskegon samples (Tukey post hoc tests, $p<0.05$, Tables 1 ) while $\mathrm{NH}_{4}{ }^{+}$ concentrations did not vary significantly with incubation time (two-way ANOVA, time effect, $\mathrm{p}=0.420$ ). In Bear samples, Pi concentration did not vary significantly among treatments (two-way ANOVA, treatment effect, $\mathrm{p}=0.161$, Tables 1 and 2) while $\mathrm{NH}_{4}^{+}$concentrations increased slightly but significantly in SEDN only (two-way ANOVA, treatment $\times$ time effect, $p<0.001$, Table 2).

\section{Microbial abundances}

Total bacterial and phytoplankton abundances in the initial control surface water sample were $1.92 \pm 0.06 \times 10^{6}$ and $0.44 \pm 0.07 \times 10^{4}$ cell $\mathrm{ml}^{-1}$ in Muskegon and $1.52 \pm 0.06 \times 10^{6}$ and $0.97 \pm 0.05 \times 10^{4}$ cell ml $^{-1}$ in Bear (Fig. 4). Differences in SEDN compared to Ctr at T0 (i.e., before incubation) suggested that sediment re-wetting resulted in suspension of bacterial cells from the sediment or potentially to growth during the 2 days of re-wetting. Indeed, at T0, bacterial cell abundances were 3.6 and 2.3 times greater in SEDN compared to Ctr, in Muskegon and Bear, respectively (two-way ANOVAs, treatment $\times$ time effect, $p<0.001$, Table 2; Fig. 4a, b). The influence of rewetting on bacterial abundance was not sustained, as 
Table 2 Results of two-way ANOVAs on bacterial and phytoplankton abundances, Pi turnover time, ATP turnover time, Pi uptake, and Pi uptake regenerated by $5^{\prime}$-nucleotidase measured for the Muskegon and Bear sites

\begin{tabular}{|c|c|c|c|c|c|c|c|c|c|c|c|c|}
\hline \multirow[t]{3}{*}{ ANOVA results } & \multicolumn{6}{|c|}{ Muskegon } & \multicolumn{6}{|l|}{ Bear } \\
\hline & \multicolumn{2}{|c|}{ Treatment } & \multicolumn{2}{|l|}{ Time } & \multicolumn{2}{|c|}{ Treatment $\times$ Time } & \multicolumn{2}{|c|}{ Treatment } & \multicolumn{2}{|l|}{ Time } & \multicolumn{2}{|c|}{ Treatment $\times$ Time } \\
\hline & $\begin{array}{l}\text { F (2, } \\
18)\end{array}$ & $p$ & $\begin{array}{l}\text { F (2, } \\
18)\end{array}$ & $p$ & $\mathrm{~F}(4,18)$ & $p$ & $\begin{array}{l}\text { F (2, } \\
18)\end{array}$ & $p$ & $\begin{array}{l}\mathrm{F}(2, \\
18)\end{array}$ & $p$ & $\mathrm{~F}(4,18)$ & $p$ \\
\hline Pi concentration & 298.9 & $<0.001$ & 43.0 & $<0.001$ & 7.66 & $<0.001$ & 2.02 & 0.161 & 8.25 & $<0.01$ & 1.95 & 0.146 \\
\hline $\mathrm{NH}_{4}{ }^{+}$concentration & 2272.5 & $<0.001$ & 0.91 & 0.420 & 15.34 & $<0.001$ & 253.1 & $<0.001$ & 12.76 & $<0.001$ & 7.44 & $<0.001$ \\
\hline Bacterial abundance & 1413.1 & $<0.001$ & 2687.0 & $<0.001$ & 843.3 & $<0.001$ & 67.2 & $<0.001$ & 362.4 & $<0.001$ & 69.8 & $<0.001$ \\
\hline $\begin{array}{l}\text { Phytoplankton } \\
\text { abundance }\end{array}$ & 39.7 & $<0.001$ & 24.1 & $<0.001$ & 37.5 & $<0.001$ & 18.0 & $<0.001$ & 0.68 & 0.518 & 1.12 & 0.378 \\
\hline \multicolumn{13}{|l|}{ Pi turnover time } \\
\hline $0.2 \mu \mathrm{m}$ & 162.5 & $<0.001$ & 86.6 & $<0.001$ & 56.8 & $<0.001$ & 5.00 & $<0.05$ & 12.47 & $<0.001$ & 5.59 & $<0.01$ \\
\hline $1.2 \mu \mathrm{m}$ & 54.9 & $<0.001$ & 4.89 & $<0.05$ & 6.61 & $<0.01$ & 14.8 & $<0.001$ & 8.44 & $<0.01$ & 1.11 & 0.385 \\
\hline \multicolumn{13}{|l|}{ ATP turnover time } \\
\hline $0.2 \mu \mathrm{m}$ & 4.93 & $<0.05$ & 6.82 & $<0.01$ & 2.33 & 0.095 & 0.86 & 0.440 & 2.83 & 0.085 & 1.05 & 0.411 \\
\hline $1.2 \mu \mathrm{m}$ & 3.12 & 0.069 & 11.0 & $<0.001$ & 3.54 & $<0.01$ & 13.3 & $<0.001$ & 4.48 & $<0.05$ & 0.06 & 0.992 \\
\hline \multicolumn{13}{|l|}{ Pi uptake } \\
\hline $0.2 \mu \mathrm{m}$ & 127.2 & $<0.001$ & 110.6 & $<0.001$ & 2.47 & 0.081 & 0.02 & 0.978 & 24.0 & $<0.001$ & 8.80 & $<0.001$ \\
\hline $1.2 \mu \mathrm{m}$ & 83.9 & $<0.001$ & 23.4 & $<0.001$ & 4.41 & $<0.05$ & 8.69 & $<0.01$ & 9.42 & $<0.01$ & 2.52 & 0.080 \\
\hline \multicolumn{13}{|c|}{ Pi uptake regenerated by 5 'nucleotidase } \\
\hline $0.2 \mu \mathrm{m}$ & 4.74 & $<0.05$ & 8.72 & $<0.01$ & 1.78 & 0.177 & 1.66 & 0.218 & 0.39 & 0.680 & 0.81 & 0.537 \\
\hline $1.2 \mu \mathrm{m}$ & 4.02 & $<0.05$ & 54.8 & $<0.001$ & 4.89 & $<0.01$ & 10.16 & $<0.01$ & 9.02 & $<0.01$ & 0.70 & 0.602 \\
\hline
\end{tabular}

Results in bold are statistically significant at $p<0.05, p<0.01$ and $p<0.001$

Fig. 4 Bacterial $\left(\times 10^{6}\right.$ cell $\left.\mathrm{ml}^{-1}\right)$ and phytoplankton $\left(\times 10^{4}\right.$ cell $\mathrm{ml}^{-1}$ ) abundances in the incubation experiment for Muskegon (a, c) and Bear (b, d), in the control (Ctr, black bars), mixed (SEDN, light grey bars) and nutrient-amended (CAN, dark grey bars) treatments at time 0,3 and 6 (T0, T3 and T6). The error bars correspond to standard deviations for triplicate incubation bottles per treatment. Significant Tukey post hoc tests, $(\mathrm{p}<0.05)$ are indicated by an asterisk between SEDN or CAN vs. Ctr treatments at each incubation time. Note the different $y$-axis scales
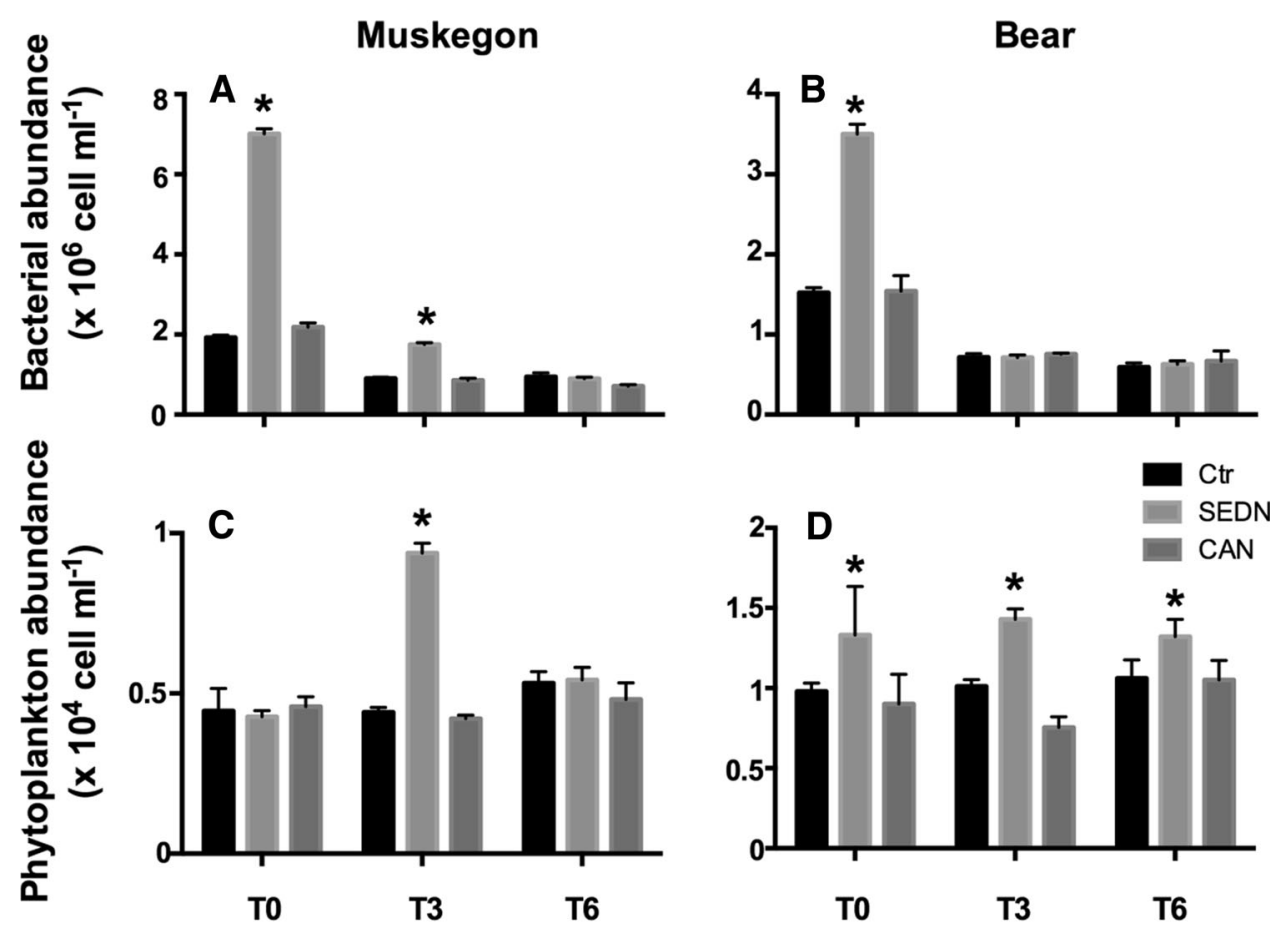
abundance values were not statistically different among treatments by day 3 in Muskegon and by day 6 in Bear (Fig. 4a, b). While phytoplankton abundances were not statistically different between treatments at T0 in Muskegon samples, they were 1.3 times greater in SEDN than in $\mathrm{Ctr}$ at $\mathrm{T} 0$ in Bear samples (Fig. 4c, d), which persisted throughout the 6-days incubation, due to an increase in all groups of naturally fluorescent cells. There was no increase in cell abundances between $\mathrm{T} 0$ and $\mathrm{T} 3$ or $\mathrm{T} 6$ in either the SEDN or CAN treatment (Fig. 4).

We also measured microbial abundance in the fraction that passed through the $1.2-\mu \mathrm{m}$-filter in control samples. We found that $69 \pm 9 \%(\mathrm{n}=9)$ and $77 \pm 10 \%(\mathrm{n}=9)$ of the bacteria were smaller than $1.2 \mu \mathrm{m}$ for Muskegon and Bear, respectively, while only $9 \pm 4 \%(\mathrm{n}=9)$ and $6 \pm 3 \%(\mathrm{n}=9)$ of the phytoplankton passed through the $1.2 \mu \mathrm{m}$ filter, for Muskegon and Bear, respectively (data not shown). Thus $\mathrm{P}$ uptake rates measured on $1.2 \mu \mathrm{m}$ filters are mostly representative of phytoplankton activity but also include $\sim 1 / 3$ of the bacterial cells.

\section{P dynamics}

The turnover times of Pi were significantly longer in Bear than in Muskegon (Fig. 5a, b) and were significantly longer in the $1.2 \mu \mathrm{m}$ than in the $0.2 \mu \mathrm{m}$ (i.e., total) fraction (1.6 vs. 1.5 times in the initial sample for Muskegon and Bear, respectively, and 1.4 vs. 2.0 times for the entire incubation period, for Muskegon and Bear, respectively). This pattern also applied to ATP turnover but to a slightly greater extent, as ATP turnover in the initial samples of the $1.2 \mu \mathrm{m}$ fraction was 2.6 and 6.0 times longer than in the total fractions, for Muskegon and Bear, respectively (Fig. 5c, d).

In Muskegon, Pi turnover times were significantly different among treatments and varied significantly with incubation time in the two size fractions (two-way ANOVAs, treatment effect, time effect, $p<0.05$, Table 2). Pi turnover time was significantly longer in CAN compared to SEDN and Ctr (Tukey post hoc tests, $p<0.05$, Fig. 5). In the CAN treatment, the turnover time of $\mathrm{Pi}$ in the $>1.2 \mu \mathrm{m}$ fraction decreased between $\mathrm{T} 0$ and $\mathrm{T} 3$ but remained longer than in Ctr and SEDN up to T6. Since Pi concentration did not decrease with incubation time, the reduction of $\mathrm{Pi}$ turnover time in the CAN treatment suggests an increase in microbial activity. Indeed, Pi uptake rate in CAN was higher at T3 than at T0 (Tukey post hoc tests, $p<0.05$, Fig. 6a).

Unlike Muskegon, Bear was not enriched in $\mathrm{Pi}$ in the SEDN and CAN treatments (Table 1) and consequently the Pi turnover time in the $>0.2 \mu \mathrm{m}$ fraction was unaffected compared to the Ctr at T0 and T6 (Tukey post hoc tests, $p<0.05$, Fig. $5 b)$. For Bear, the turnover time of ATP was not significantly different among treatments and with incubation time in the $>0.2 \mu \mathrm{m}$ fraction (two-way
Fig. 5 Pi (a, b) and ATP (c, d) turnover time (d) in the incubation experiment for Muskegon (a, c) and Bear (b, d) and in the $>0.2 \mu \mathrm{m}$ (black bars) and $>1.2 \mu \mathrm{m}$ (grey bars) fractions. Rest of legend as in Fig. 4

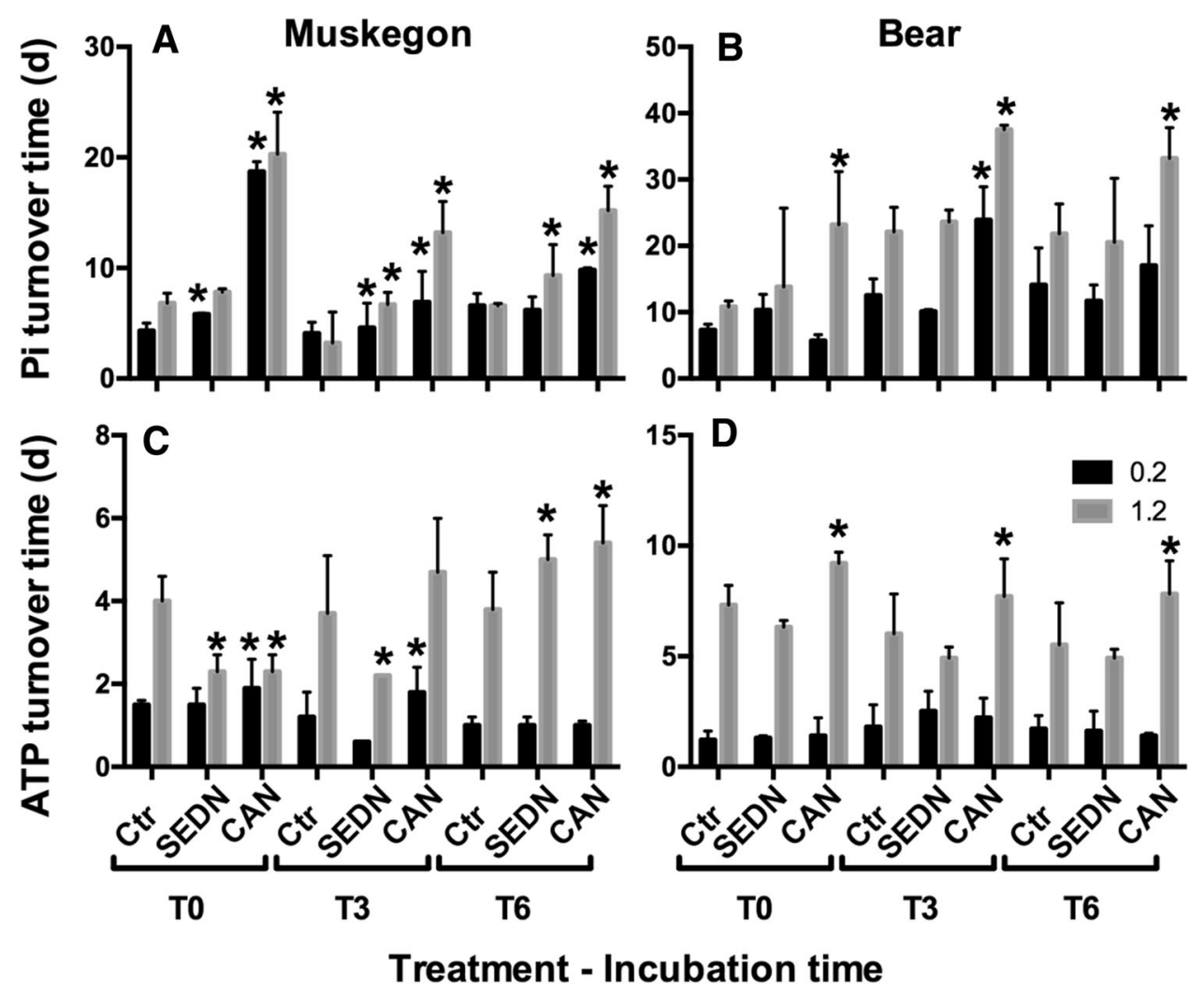


Fig. 6 Pi uptake rates $\left(\mu \mathrm{mol} \mathrm{l}^{-1} \mathrm{~d}^{-1}\right)$ in the incubation experiment for Muskegon (a) and Bear (b) and in the $>0.2 \mu \mathrm{m}$ (black bars) and $>1.2 \mu \mathrm{m}$ (grey bars) fractions. Rest of legend as in Fig. 4
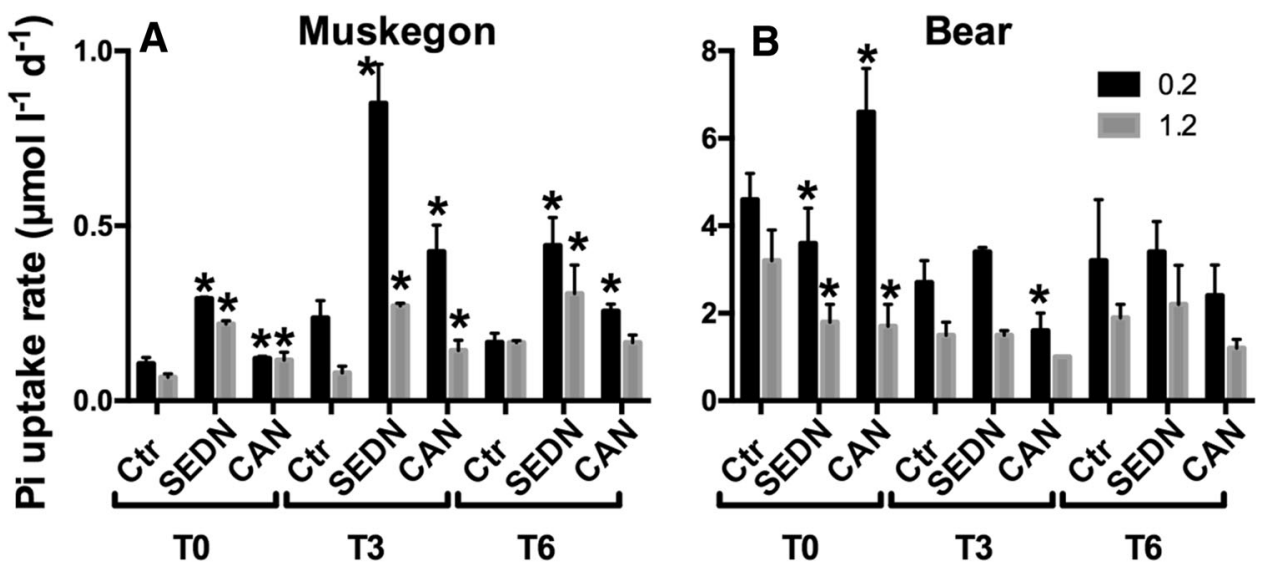

Treatment - Incubation time
ANOVA, treatment effect, time effect, $\mathrm{p}>0.05$, Table 2). In the $1.2 \mu \mathrm{m}$ fraction, only the CAN treatment had a significant effect with longer turnover time of ATP between $\mathrm{T} 0$ and $\mathrm{T} 6$ compared to the $\mathrm{Ctl}$ and SEDN treatments (Fig. 5d).

Pi uptake rates were 43 times higher in the initial surface water sample in Bear than in Muskegon (Fig. 6), reflecting at least in part the much higher Pi concentrations in the Bear surface water compared to Muskegon (Table 1). In Muskegon, Pi uptake rates were significantly higher in the SEDN than in the Ctr and CAN treatments (two-way ANOVA, treatment effect, $p<0.001$, Table 2, Fig. 6a). Pi uptake rates in the SEDN and CAN treatments were $2.7 \pm 0.2$-fold and $1.5 \pm 0.2$-fold higher than in the $\mathrm{Ctr}$ at T6, respectively, implying higher microbial activities in the SEDN than in the CAN treatments. This was also illustrated in cell specific rates with similar rates at $\mathrm{T} 0$ $\left(0.04 \pm 0.17,0.03 \pm 0.02\right.$ and $0.04 \pm 0.08 \mathrm{fmol} \mathrm{cell}^{-1}$ $\mathrm{d}^{-1}$, in Ctr, SEDN and CAN, respectively). In Bear there were no significant changes in $\mathrm{Pi}$ uptake rates among treatments in the $>0.2$ fraction, except in CAN at T0 where $\mathrm{Pi}$ uptake rates were $1.5 \pm 0.2$-fold higher than in $\mathrm{Ctrl}$ (two-way ANOVA, treatment $\times$ time effect, $\mathrm{p}<0.001$, Table 2; Fig. 6b).

At T0, $24 \pm 5$ and $14 \pm 5 \%$ of the Pi regenerated by $5^{\prime}$-nucleotidase was taken up by the whole community $(>0.2 \mu \mathrm{m}$ fraction) in Muskegon and Bear, respectively. The percent uptake of Pi regenerated by $5^{\prime}$-nucleotidase in the $>0.2 \mu \mathrm{m}$ fraction was significantly higher in SEDN and lower in CAN than in the other treatments at $\mathrm{T} 3$ in Muskegon samples (Fig. 7). No differences among treatments were recorded for Bear in the $>0.2 \mu \mathrm{m}$ fraction (two-way ANOVA, treatment effect, $p=0.218$, Table 2). The uptake of Pi regenerated by $5^{\prime}$-nucleotidase at $\mathrm{T} 0$ was much lower in the $>1.2 \mu \mathrm{m}$ fraction than in the $>0.2 \mu \mathrm{m}$ fraction with $9 \pm 2$ and $2.2 \pm 0.2 \%$ in Muskegon and
Bear, respectively. Although the percent uptake of $\mathrm{Pi}$ regenerated by $5^{\prime}$-nucleotidase in the $>1.2 \mu \mathrm{m}$ fraction was significantly higher in SEDN and CAN at T0 in Muskegon samples, there was no significant differences with the control at T3 and T6 (Fig. 7). In Bear, the percent uptake of Pi regenerated by $5^{\prime}$-nucleotidase in the $>1.2 \mu \mathrm{m}$ fraction was significantly lower in CAN during the whole experiment (Fig. 7).

\section{Microbial community structure and contribution to Pi and ATP turnover}

At the start of the experiment, we identified four cell populations in the SG stained samples: S1, S2, S3 and S4. $\mathrm{S} 1, \mathrm{~S} 2$ and $\mathrm{S} 3$ have the same characteristics as previously described bacteria with low nucleic acid content (S1), high nucleic acid content and higher light scatter (S2), and bacteria with high nucleic acid content and high light scatter (S3) (Tadonleke et al. 2005; Vila-Costa et al. 2012). The S4 cell population has no clear correspondence, and was not significantly correlated to any of the phytoplankton cell populations. Moreover, S4 abundances were $\sim 25$-fold more abundant than total phytoplankton in the initial sample. Thus it is likely that S4 corresponded to large bacteria in the size range of $\mathrm{S} 3$ but with a smaller nucleic acid content, as evidenced by its lower fluorescence in the green channel. S2 was the most abundant bacterial cell population in both Muskegon and Bear, representing 55 and $72 \%$ of total relative bacterial abundance, respectively. S1 was next most abundant with 36 and $25 \%$, respectively (Fig. 8a, b). S3 and S4 accounted for less than $10 \%$ of total relative abundance.

The suspension or growth of bacterial cells from the sediment after re-wetting resulted in changes to the microbial community structure in SEDN compared to Ctr or CAN (Fig. 8a, b). In Muskegon, this increase was 
Fig. 7 Uptake of Pi regenerated by $5^{\prime}$-nucleotidase $(\%)$ in the incubation experiment for Muskegon (a) and Bear (b) and in the $>0.2 \mu \mathrm{m}$ (black bars) and $>1.2 \mu \mathrm{m}$ (grey bars) fractions. Rest of legend as in Fig. 4

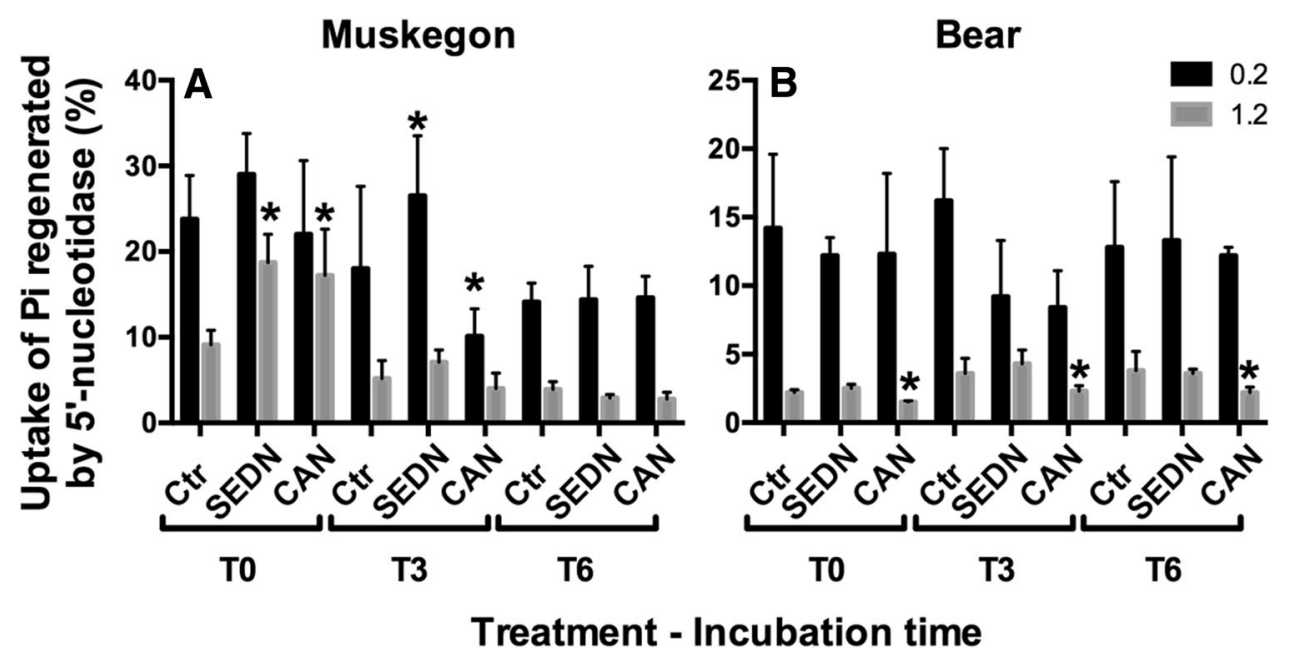

Muskegon

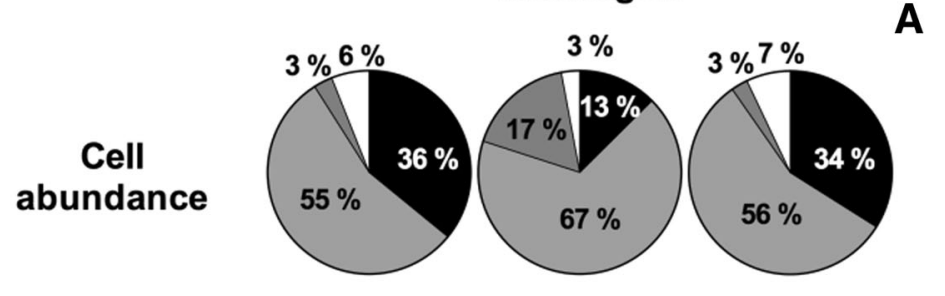

A

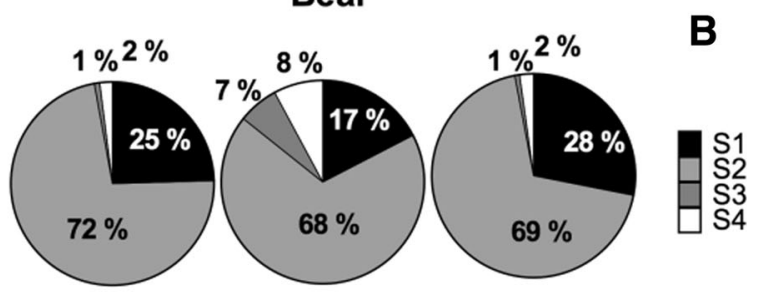

C

Pi turnover rate

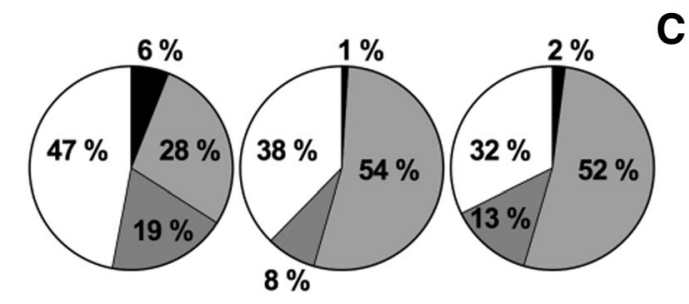

ATP turnover
rate

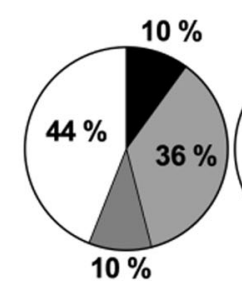

Ctr

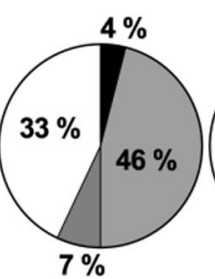

SEDN

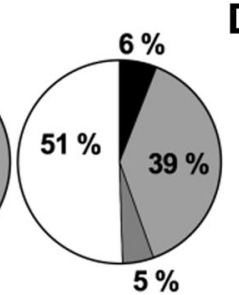

CAN
D

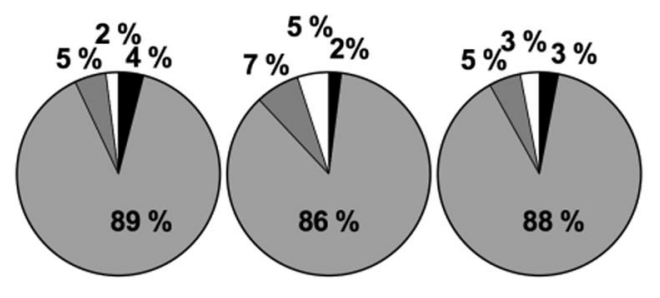

E

Fig. 8 Pie charts of the bacterial cell populations S1, S2, S3 and S4 (in black, light grey, dark grey and white, respectively) contribution to total cell abundance $(\mathbf{a}, \mathbf{b})$, Pi turnover rate $(\mathbf{c})$ and ATP turnover rate $(\mathbf{d}, \mathbf{e})$ at $\mathrm{T} 0$, for Muskegon $(\mathbf{a}, \mathbf{c}, \mathbf{d})$ and Bear $(\mathbf{b}, \mathbf{e})$ in the $\mathrm{Ctr}$,

observed in S2 and S3, the groups of bacteria with larger size and higher nucleic acid content, whereas S1 declined relative to CAN and Ctr. In Bear, re-wetting positively affected S3 and S4, which were 17.4 and 9.0 times more abundant in SEDN than in Ctr, respectively, and similar to Muskegon, re-wetting negatively affected S1.
The contribution of the four bacterial cell populations to $\mathrm{P}$ dynamics was quite different between Muskegon and Bear (Fig. 8d, e). In particular, S4 accounted for 33 to $51 \%$ of ATP turnover in Muskegon at T0 but only 2-5\% in Bear. At T6, there were no variations in the contribution of the different cell populations to ATP turnover in 
Muskegon samples while in Bear the contribution of S3 and $\mathrm{S} 1$ in both SEDN and CAN tended to increase (to $\sim 25$ and $15 \%$ ) while that of S2 decreased (data not shown). In Muskegon, the contribution of the different bacterial cell populations to Pi turnover rate was similar to that for ATP and there were no large changes with incubation time. Because of high isotopic dilution in Bear, Pi uptake rates were low and could not be accurately measured in the four bacterial cell populations, preventing calculation of the contribution of the different bacterial cell populations to total Pi turnover rate in Bear.

\section{Discussion}

Desiccation of lake sediment after water level recession, followed by re-inundation (either from storm runoff, seiches, or direct precipitation), can lead to sediment-water nutrient exchange through chemical (e.g., redox) and biological (e.g., activation of P-mineralizing enzymes; lysing of bacterial cells) changes (Song et al. 2007; Steinman et al. 2012, 2014; Gilbert et al. 2014; Orihel et al. 2015). Yet little is known about the composition and fate of these nutrients released in the surface water of freshwater coastal wetlands and how they affect the microbial communities inhabiting the water column. In this study, we examined the effect of both nutrient concentration and source on microbes inhabiting the water column, and the role of these microbes in the fate of the released nutrients. We report information on nutrient release for the most bioavailable and preferred forms of $\mathrm{N}$ and $\mathrm{P}$ to the microbial community: $\mathrm{NH}_{4}{ }^{+}$and $\mathrm{Pi}$, respectively. We acknowledge that the sediment may release other forms of $\mathrm{N}$ and $\mathrm{P}$, although our analyses indicated that DOP was not a substantial source of $\mathrm{P}$.

\section{Nutrient release from the sediment after drying/re-wetting}

As expected, a cycle of desiccation and re-wetting resulted in sediment nutrient release into surface water, especially at the Muskegon wetland. These nutrient releases were in the lower range of values found in the literature (Schonbrunner et al. 2012, Steinman et al. 2012, 2014; Gilbert et al. 2014) possibly because of the relatively low organic matter content (Reddy and Dangelo 1997).

We hypothesized that sediment nutrient release would be greater in Bear than in Muskegon, given that the Bear Lake muck field sediment had higher nutrient concentrations than Muskegon Lake sediment. However, we found little support for this hypothesis. Bear Lake muck field sediment released less $\mathrm{NH}_{4}{ }^{+}$than Muskegon and no net Pi. The lack of Pi release may be due to the very high Pi concentrations in the water column of the Bear Lake muck field, resulting in a small or non-existent concentration gradient between the sediment and water column (cf. Smit and Steinman 2015). Moreover the sediment collected from the Bear site was sandy and relatively low in OM, which may have constrained nutrient release (Reddy and Dangelo 1997).

Microbial responses to DWE-induced nutrient enrichment in surface water

The second phase of this study assessed the water column microbial response to different types of nutrient enrichment. Microbial communities are critical channels of energy and material flows in aquatic ecosystems (Azam et al. 1983; Cotner and Biddanda 2002) and can show dramatic responses to nutrient inputs (Coveney and Wetzel 1992; Elser et al. 1995; Camacho et al. 2003). In nutrient limited environments, studies have demonstrated that aquatic microbial communities bloom in response to nutrient addition, with a maximum response usually within 6 days (Hecky and Kilham 1988; Elser et al. 1995; Berdalet et al. 1996). Yet it is unclear how microbes respond to nutrient addition in $\mathrm{P}$ replete habitats, as is the case in wetlands that are associated with eutrophic lakes or are being restored from former agricultural land uses (e.g., Ardón et al. 2010, Steinman and Ogdahl 2011), and if the nutrients released from the sediment are bioavailable.

Here we showed that after re-wetting the sediment from both sites, large amounts of bacterial cells were recovered in the supernatant after re-wetting. Yet after incubating the supernatant for 3 and 6 days with surface water, bacterial abundances in the SEDN treatment decreased to the levels in the initial Ctr (but were still significantly greater than $\mathrm{Ctr}$ or CAN on day 3), suggesting that the cells suspended from the sediment either did not grow or did not exhibit net positive growth, or were grazed by protists smaller than $63-\mu \mathrm{m}$. We speculate that the suspended bacterial cells were primarily benthic in nature, and hence were incapable of growing in the water column. However, in natural wetlands, where wave action can occur in contrast to our microcosms, active metabolism and growth of suspended and advected bacterial cells may be more plausible. It is also possible that a portion of the increase in measured $\mathrm{Pi}$ originated from mineralized bacterial cells (cf. Sparling et al. 1985).

The relatively high ambient $\mathrm{Pi}$ concentrations and long turnover times, especially in Bear, measured in surface water samples indicate that $\mathrm{Pi}$ was at a saturating concentration at both locations. This is consistent with the lack of change in $\mathrm{Pi}$ uptake rate with increasing $\mathrm{Pi}$ additions, making the determination of the Michaelis-Menten kinetics impossible. Thus microbes inhabiting the surface water 
of these wetlands were P-replete and their Pi uptake systems were already saturated at the start of our experiment. Aquatic bacteria and phytoplankton typically prefer Pi and $\mathrm{NH}_{4}{ }^{+}$because the energetic cost for assimilating these forms is lower than for other sources of $\mathrm{P}$ and $\mathrm{N}$ (Cembella et al. 1984; Kirchman 2000; Gardner et al. 2004). The $\mathrm{NH}_{4}{ }^{+}$to $\mathrm{Pi}$ molar ratios of 159 and 2.5 measured in Muskegon and Bear surface water suggest P-stress and $\mathrm{N}$-stress, respectively. Yet, we saw no increase in cell abundances with incubation time following nutrient additions in either the SEDN or CAN treatment compared to the control. This indicates that microbial growth was not limited by nutrient availability in these wetland surface waters, and that the $\mathrm{NH}_{4}^{+}$to $\mathrm{Pi}$ molar ratio had little ecological significance because of the high absolute nutrient concentrations. Thus, in these P-replete environments, we find limited support for the hypotheses that bacteria and phytoplankton abundance would increase in response to increasing nutrient concentration, and SEDN would stimulate greater microbial growth than CAN because of greater concentrations of DOP. A lack of increase in cell abundance with incubation time in nutrient amended surface water also has been found in eutrophic lakes (Schindler et al. 2008; Newton and McMahon 2011). Yet, it is possible that bacterial community composition may have changed in response to nutrient amendments while keeping overall abundance relatively constant.

At the start of the experiment, the relative abundance of four bacterial cell populations identified by flow cytometry (S1, S2, S3 and S4) was altered in the SEDN treatment compared to the Ctr, indicating that WLF can affect microbial community composition. We hypothesized that these observed changes in the microbial community composition could affect the $\mathrm{P}$ dynamics in the water column. To test this hypothesis we measured group-specific $\mathrm{P}$ uptake. Our results showed that S1 comprised roughly a quarter of total bacterial abundance but accounted for a very small fraction of Pi and ATP uptake, suggesting that they may be dormant, as previously described for low nucleic acid content bacterial populations ( $\mathrm{Li}$ et al. 1995; Lebaron et al. 2001; Servais et al. 2003). In contrast, the S4 population represented a small fraction of total bacterial abundance but accounted for a large fraction of $\mathrm{P}$ turnover. Thus in environments where bacterial growth is stimulated by the addition of nutrients from the sediment, nutrient cycling could be greatly modified by changes in the community structure and relative abundance of different microbial groups. This may be especially relevant in coastal wetlands because of differential responses of microbial groups to the availability of inorganic vs. organic P (Tarapchak and Moll 1990; Thingstad et al. 1993).

The microbial response experiment also examined the bioavailability of the nutrient released from the sediment.
The addition of Pi $\left(+1.26\right.$ and $1.83 \mu \mathrm{mol} \mathrm{l}^{-1}$, measured in SEDN and CAN, respectively) resulted in a 4.4 times increase in total Pi turnover at T0 in the Muskegon CAN treatment, whereas it increased turnover by only 1.4 times in the SEDN treatment. This implies that at equivalent concentrations, the Pi released from the sediment may not be as bioavailable as the commercial solution of $\mathrm{KH}_{2} \mathrm{PO}_{4}$. The mechanism behind this unexpected result is unclear; possible explanations include the Pi was bound to colloids and hence not readily available or compounds released from the sediment deterred uptake rates. More study is needed to better understand these processes.

When DOP in the sediment is exposed to the air, its chemistry can be altered by photo-oxidation and biodegradation (Feng et al. 2011), often increasing its bioavailability. Previous studies have shown that DOP is the most bioavailable part of dissolved organic matter and that it can be rapidly recycled (Paytan et al. 2003; White et al. 2012). DOP is usually quantified indirectly by subtracting Pi from total dissolved $\mathrm{P}$, each of which are subject to measurement errors (Monaghan and Ruttemberg 1999; Jarvie et al. 2002; Karl and Björkman 2002). Thus, DOP estimates are prone to high variability. We do not report the DOP results for the microbial response experiment, as the estimated concentrations were low ( $\sim 11 \%$ of TP) and the variation in DOP measurements (detection limit: $0.4 \mu \mathrm{M}$ ) often exceeded variation among treatments and incubation times. Nonetheless, given the significant increase in $\mathrm{Pi}$ concentrations measured in Muskegon samples, it is certainly plausible that DOP was hydrolyzed. This suggests that the microbial community in our study retains the enzymatic capacity to hydrolyze DOP. It is unlikely that increased DOP bioavailability was due to sediment release, as controls showed similar results to the SEDN treatment. Although results from chemical analysis are inconclusive, the lack of a difference in total ATP turnover time between the SEDN and CAN treatments suggests that the DOP released from the sediment was not more labile than the DOP present in the water column before treatment. However, because DOP utilization is up-regulated in P-stressed and P-limited environments (Dyhrman and Ruttenberg 2006; Duhamel et al. 2010), the hypothesis that DOP released from the sediment is more bioavailable than the one in the water column may still be valid in P-limited coastal wetlands, and needs to be tested.

\section{Conclusion}

The nutrient replete Muskegon and Bear coastal wetlands presented large differences in their nutrient and microbial composition both in the sediment and water column. Muskegon was characterized by lower $\mathrm{Pi}$ and $\mathrm{NH}_{4}{ }^{+}$ 
concentrations in surface water samples than Bear. Yet, Muskegon sediments released larger amounts of both Pi and $\mathrm{NH}_{4}{ }^{+}$than Bear sediments following a period of desiccation (2 months) and re-wetting ( 2 days). In both systems, the microbial community abundance and structure in the surface water increased and was altered, respectively, after mixing with water used to re-wet the sediment. Results from microbial response experiment showed that the microbial communities in the surface water from both wetlands did not exhibit net growth following commercially available nutrient amendments or from the nutrients associated with sediment release after re-wetting. Yet, the relative abundance of four bacterial cell groups identified by flow cytometry and their relative contribution to $\mathrm{P}$ uptake were altered in SEDN and CAN, showing clearly that, as for phytoplankton, bacterioplankton functional traits are variable and should not be studied as one ecological group. Although Pi uptake rates increased in the Piamended treatments (in both SEDN and CAN), Pi concentration remained high and Pi turnover stayed long over the 6 days of the microbial response experiment. These results have ecological implications for coastal wetlands based on their geomorphology. In protected coastal wetlands, with limited hydrologic exchange and high nutrient concentrations, nutrient release from DWE will be retained in the system, further driving eutrophication. Alternatively, in open wetland systems with considerable hydrologic exchange, nutrient release across the sediment-water interface can be advected to the nearshore zone, thereby outwelling organic matter and nutrients from these Lake coastal habitats and driving ecosystem productivity (Cooper et al. 2013).

Acknowledgments We thank the following individuals who assisted with either sample collection or analyses: Dr. Bopi Biddanda, Anna Harris, James Smit, Brian Scull, Kurt Thompson and Maggie Weinert. Financial support was generously provided by an anonymous gift in memory of Donald L. and Patrice S. Bailey, and the Anonymous Fund at the Community Foundation for Muskegon County.

\section{References}

Aghaeepour N, Nikolic R, Hoos HH, Brinkman RR (2011) Rapid cell population identification in flow cytometry data. Cytometry A 79:6-13

Ammerman JW (1993) Microbial cycling of inorganic and organic phosphorus in the water column. In: Kemp PF, Sherr BF, Sherr EB, Cole JJ (eds) Handbook of methods in aquatic microbial ecology. Lewis Publishers, Boca Raton, pp 649-660

Ammerman JW, Azam F (1985) Bacterial 5-nucleotidase in aquatic ecosystems: a novel mechanism of phosphorus regeneration. Science 227:1338-1340

Ammerman JW, Azam F (1991) Bacterial 5'-nucleotidase activity in estuarine and coastal marine waters: characterization of enzyme activity. Limnol Oceanogr 36:1427-1436
APHA (2005) Standard methods for the examination of water and waste water, 21st edn. American Public Health Association, Washington, DC

Ardón M, Morse J, Doyle M, Bernhardt E (2010) The water quality consequences of restoring wetland hydrology to a large agricultural watershed in the southeastern coastal plain. Ecosystems 13:1060-1078

Azam F, Frenchel T, Field JG, Gray JS, Meyer-Reil LA, Thingstad TF (1983) The ecological role of water-column microbes in the sea. Mar Ecol Prog Ser 10:257-263

Baldwin DS (1996) Effects of exposure to air and subsequent drying on the phosphate sorption characteristics of sediments from a eutrophic reservoir. Limnol Oceanogr 41:1725-1732

Berdalet E, Marrase C, Estrada M, Arin L, MacLean ML (1996) Microbial community responses to nitrogen- and phosphorusdeficient nutrient inputs: microplankton dynamics and biochemical characterization. J Plankton Res 18:1627-1641

Biddanda B, Ogdahl M, Cotner J (2001) Dominance of bacterial metabolism in oligotrophic relative to eutrophic waters. Limnol Oceanogr 46:730-73910

Björkman KM, Duhamel S, Karl DM (2012) Microbial group specific uptake kinetics of inorganic phosphate and adenosine-5'-triphosphate (ATP) in the North Pacific Subtropical Gyre. Front Microbiol 3:1-17

Boström B, Jansson M, Forsberg C (1982) Phosphorus release from lake sediments. Archiv für Hydrobiologie-Beiheft Ergebnisse der Limnologie 18:5-59

Camacho A, Wurtsbaugh WA, Miracle MR, Armengol X, Vicente E (2003) Nitrogen limitation of phytoplankton in a Spanish karst lake with a deep chlorophyll maximum: a nutrient enrichment bioassay approach. J Plankton Res 25:397-404

Casey JR, Lomas MW, Michelou VK, Dyhrman ST, Orchard ED, Ammerman JW, Sylvan JB (2009) Phytoplankton taxon-specific orthophosphate (Pi) and ATP utilization in the western subtropical North Atlantic. Aquat Microb Ecol 58:31-44

Cembella AD, Antia NJ, Harrison PJ (1984) The utilization of inorganic and organic phosphorus compounds as nutrients by eukaryotic microalgae: a multidisciplinary perspective: part 1 . Crit Rev Microbiol 10:317-391

Cook BI, Ault TR, Smerdon JE (2015) Unprecedented 21st century drought risk in the American Soutwest and Central Plains. Sci Adv 1:e1400082

Cooper MJ, Steinman AD, Uzarski DG (2013) Influence of geomorphic setting on the metabolism of Lake Huron fringing wetlands. Limnol Oceanogr 58:452-464

Costanza R, dArge R, deGroot R, Farber S, Grasso M, Hannon B, Limburg K, Naeem S, Oneill RV, Paruelo J, Raskin RG, Sutton P, vandenBelt M (1997) The value of the world's ecosystem services and natural capital. Nature 387:253-260

Cotner JB, Biddanda BA (2002) Small players, large role: microbial influence on biogeochemical processes in pelagic aquatic ecosystems. Ecosystems 5:105-121

Coveney MF, Wetzel RG (1992) Effects of nutrients on specific growth rate of bacterioplankton in oligotrophic lake water cultures. Appl Environ Microbiol 58:150-156

Cymbola J, Ogdahl M, Steinman AD (2008) Phytoplankton response to light and internal phosphorus loading from sediment release. Freshw Biol 53:2530-2542

De Groot R, Brander L, Van Der Ploeg S, Costanza R, Bernard F, Braat L, Christie M, Crossman N, Ghermandi A, Hein L, Hussain S, Kumar P, Mcvittie A, Portela R, Rodriguez LC, Ten Brink P, Van Beukering P (2012) Global estimates of the value of ecosystems and their services in monetary units. Ecosyst Serv 1:50-61

Duhamel S, Dyhrman ST, Karl DM (2010) Alkaline phosphatase activity and regulation in the North Pacific Subtropical Gyre. Limnol Oceanogr 55:1414-1425 
Duhamel S, Björkman KM, Van Wambeke F, Moutin T, Karl DM (2011) Characterization of alkaline phosphatase activity in the North and South Pacific Subtropical Gyres: implications for phosphorus cycling. Limnol Oceanogr 56:1244-1254

Duhamel S, Björkman KM, Karl DM (2012) Light dependence of phosphorus uptake by microorganisms in the North and South Pacific subtropical gyres. Aquat Microb Ecol 67:225-238

Duhamel S, Björkman KM, Doggett JK, Karl DM (2014) Microbial response to enhanced phosphorus cycling in the North Pacific Subtropical Gyre. Mar Ecol Prog Ser 504:43-58

Dyhrman S, Ruttenberg KC (2006) Presence and regulation of alkaline phosphatase activity in eukaryotic phytoplankton from the coastal ocean: implications for dissolved organic phosphorus remineralization. Limnol Oceanogr 51:1381-1390

Elser JJ, Stabler LB, Hassett RP (1995) Nutrient limitation of bacterial growth and rates of bacterivory in lakes and oceans: a comparative study. Aquat Microb Ecol 9:105-110

Feng XJ, Hills KM, Simpson AJ, Whalen JK, Simpson MJ (2011) The role of biodegradation and photo-oxidation in the transformation of terrigenous organic matter. Org Geochem 42:262-274

Gardner WS, Lavrentyev PJ, Cavaletto JF, McCarthy MJ, Eadie BJ, Johengen TH, Cotner JB (2004) Distribution and dynamics of nitrogen and microbial plankton in southern Lake Michigan during spring transition 1999-2000. J Geophys Res-Oceans 109:C03007

Gilbert JD, Guerrero F, de Vicente I (2014) Sediment desiccation as a driver of phosphate availability in the water column of Mediterranean wetlands. Sci Total Environ 466:965-975

Gronewold AD, Clites AH, Smith JP, Hunter TS (2013) A dynamic graphical interface for visualizing projected, measured, and reconstructed surface water elevations on the earth's largest lakes. Environ Model Softw 49:34-39

Hecky RE, Kilham P (1988) Nutrient limitation of phytoplankton in freshwater and marine environments: a review of recent evidence on the effects of enrichment. Limnol Oceanogr 33:796-822

IPCC (2007) Contribution of Working Group I to the Fourth Assessment Report of the Intergovernmental Panel on Climate Change. In: Solomon S, Qin D, Manning M, Chen Z, Marquis M, Averyt KB, Tignor M, Miller HL (eds) Cambridge University Press, Cambridge, United Kingdom and New York, NY, USA

IUGLS IUGLS (2012) Lake Superior regulation: addressing uncertainty in upper Great Lakes water levels. In: Final Report to the International Joint Commission, Book Cat. No. E95-2/15-2012E

Jarvie HP, Withers PJA, Neal C (2002) Review of robust measurement of phosphorus in river water: sampling, storage, fractionation and sensitivity. Hydrol Earth Syst Sci 6:113-131

Jensen A (1984) Excretion of organic carbon as function of nutrient stress. In: Holm-Hansen O, Bolis L, Gilles R (eds) Lecture notes on coastal and estuarine studies, vol 8. Springer, Berlin, pp 61-72

Karl DM, Björkman K (2002) Dynamics of DOP. In: Carlson CA, Hansell DA (eds) Biogeochemistry of marine dissolved organic matter. Academic Press, Dublin, pp 249-366

Kayranli B, Scholz M, Mustafa A, Hedmark A (2010) Carbon storage and fluxes within freshwater wetlands: a critical review. Wetlands 30:111-124

Kirchman DL (2000) Uptake and regeneration of inorganic nutrients by marine heterotrophic bacteria. In: Kirchman DL (ed) Microbial ecology of the oceans. Wiley, New York, pp 261-288

Lean DRS, Nalewajko C (1979) Phosphorus turnover time and phosphorus demand in large and small lakes. Ergebnisse der Limnologie 13:120-132

Lebaron P, Servais P, Agogu H, Courties C, Joux F (2001) Does the high nucleic acid content of individual bacterial cells allow us to discriminate between active cells and inactive cells in aquatic systems? Appl Environ Microbiol 67:1775-1782
Li WKW, Jellett JF, Dickie PM (1995) DNA distributions in planktonic bacteria stained with TOTO or TO-PRO. Limnol Oceanogr 40:1485-1495

Malej A, Mozetic P, Turk V, Terzic S, Ahel M, Cauwet G (2003) Changes in particulate and dissolved organic matter in nutrientenriched enclosures from an area influenced by mucilage: the northern Adriatic Sea. J Plankton Res 25:949-966

Michelou VK, Lomas MW, Kirchman DL (2011) Phosphate and adenosine- $5^{\prime}$-triphosphate uptake by cyanobacteria and heterotrophic bacteria in the Sargasso Sea. Limnol Oceanogr 56:323-332

Monaghan EJ, Ruttemberg KC (1999) Dissolved organic phosphorus in the coastal ocean: reassessment of available methods and seasonal phosphorus profiles from the Eel River Shelf. Limnol Oceanogr 44:1702-1714

Newton RJ, McMahon KD (2011) Seasonal differences in bacterial community composition following nutrient additions in a eutrophic lake. Environ Microbiol 13:887-899

Orihel DM, Schindler DW, Ballard NC, Graham MD, O'Connell DW, Wilson LR, Vinebrooke RD (2015) The "nutrient pump:" Ironpoor sediments fuel low nitrogen-to-phosphorus ratios and cyanobacterial blooms in polymictic lakes. Limnol Oceanogr 60:856-871

Paytan A, Cade-Menun BJ, McLaughlin K, Faul KL (2003) Selective phosphorus regeneration of sinking marine particles: evidence from 31P-NMR. Mar Chem 82:55-70

Reddy KR, Dangelo EM (1997) Biogeochemical indicators to evaluate pollutant removal efficiency in constructed wetlands. Water Sci Technol 35:1-10

R Core Team (2014) R: A language and environment for statistical computing. R Foundation for Statistical Computing, Vienna, Austria. http://www.R-project.org/

Sabater S, Tockner K (2010) Effects of hydrologic alterations on the ecological quality of river ecosystems. Water Scarcity Mediterr: Perspect under Glob Chang 8:15-39

Schindler DW, Hecky RE, Findlay DL, Stainton MP, Parker BR, Paterson MJ, Beaty KG, Lyng M, Kasian SEM (2008) Eutrophication of lakes cannot be controlled by reducing nitrogen input: results of a 37-year whole-ecosystem experiment. Proc Natl Acad Sci USA 105:11254-11258

Schonbrunner IM, Preiner S, Hein T (2012) Impact of drying and reflooding of sediment on phosphorus dynamics of river-floodplain systems. Sci Total Environ 432:329-337

Servais P, Casamayor EO, Courties C, Catala P, Parthuisot N, Lebaron P (2003) Activity and diversity of bacterial cells with high and low nucleic acid content. Aquat Microb Ecol 33:41-51

Sierszen ME, Morrice JA, Trebitz AS, Hoffman JC (2012) A review of selected ecosystem services provided by coastal wetlands of the Laurentian Great Lakes. Aquat Ecosyst Health Manag 15:92-106

Smit JT, Steinman AD (2015) Wetland sediment phosphorus flux in response to proposed hydrologic reconnection and warming. Wetlands. doi:10.1007/s13157-015-0655-1

Smith VH, Tilman GD, Nekola JC (1999) Eutrophication: impacts of excess nutrient inputs on freshwater, marine, and terrestrial ecosystems. Environ Pollut 100:179-196

Song KY, Zoh KD, Kang H (2007) Release of phosphate in a wetland by changes in hydrological regime. Sci Total Environ 380:13-18

Sparling GP, Whale KN, Ramsay AJ (1985) Quantifying the contribution from the soil microbial biomass to the extractable P level of fresh and air-dried soils. Aust J Soil Res 23:613-621

Steinman AD, Ogdahl ME (2011) Does converting agricultural fields to wetlands retain or release P? J North Am Benthol Soc 30:820-830

Steinman AD, Ogdahl M, Rediske R, Ruetz CR, Biddanda BA, Nemeth L (2008) Current status and trends in Muskegon Lake, Michigan. J Great Lakes Res 34:169-188 
Steinman AD, Ogdahl ME, Weinert M, Thompson K, Cooper MJ, Uzarski DG (2012) Water level fluctuation and sediment-water nutrient exchange in Great Lakes coastal wetlands. J Great Lakes Res 38:766-775

Steinman AD, Ogdahl ME, Weinert M, Uzarski DG (2014) Influence of water-level fluctuation duration and magnitude on sediment-water nutrient exchange in coastal wetlands. Aquat Ecol 48:143-159

Stern J, Wang Y, Gu B, Newman J (2007) Distribution and turnover of carbon in natural and constructed wetlands in the Florida Everglades. Appl Geochem 22:1936-1948

Tadonleke RD, Planas D, Lucotte A (2005) Microbial food webs in boreal humic lakes and reservoirs: ciliates as a major factor related to the dynamics of the most active bacteria. Microb Ecol 49:325-341

Talarmin A, Van Wambeke F, Duhamel S, Catala P, Moutin T, Lebaron P (2011) Improved methodology to measure taxonspecific phosphate uptake in live and unfiltered samples. Limnol Oceanogr Methods 9:443-453

Tarapchak SJ, Moll RA (1990) Phosphorus sources for phytoplankton and bacteria in Lake Michigan. J Plankton Res 12:743-758

Thingstad TF, Skjoldal EF, Bohne RA (1993) Phosphorus cycling and algal-bacterial competition in Sandsfjord, western Norway. Mar Ecol—Prog Ser 99:239-259

Trebitz AS, Morrice JA, Cotter AM (2002) Relative role of lake and tributary in hydrology of Lake Superior coastal wetlands. J Great Lakes Res 28:212-227

USEPA UEA (1983) Methods for chemical analysis of water and wastewater. In: National Exposure Research Laboratory, US Environmental Protection agency, Book EPA-600/4-79-020, Cincinnati, Ohio
Vila-Costa M, Gasol JM, Sharma S, Moran MA (2012) Community analysis of high- and low-nucleic acid-containing bacteria in NW Mediterranean coastal waters using 16S rDNA pyrosequencing. Environ Microbiol 14:1390-1402

Vitousek PM, Aber JD, Howarth RW, Likens GE, Matson PA, Schindler DW, Schlesinger WH, Tilman D (1997) Human alteration of the global nitrogen cycle: sources and consequences. Ecol Appl 7:737-750

Wang L, Liang T (2015) Distribution characteristics of phosphorus in the sediments and overlying water of Poyang Lake. PLoS One 10(5):e0125859. doi:10.1371/journal.pone.0125859

Wantzen KM, Junk WJ, Rothhaupt K-O (2008) An extension of the floodpulse concept (FPC) for lakes. Hydrobiologia 613:151-170

Weatherburn MW (1967) Phenol-hypochlorite reaction for determination of ammonia. Anal Chem 39:971

White AE, Watkins-Brandt KS, Engle MA, Burkhardt B, Paytan A (2012) Characterization of the rate and temperature sensitivities of bacterial rem ineralization of dissolved organic phosphorus compounds by natural populations. Front Microbiol 3:276. doi:10.3389/fmicb.2012.00276

Zhou QX, Gibson CE, Zhu YM (2001) Evaluation of phosphorus bioavailability in sediments of three contrasting lakes in China and the UK. Chemosphere 42:221-225

Zubkov MV, Mary I, Malcolm E, Woodward S, Warwick PE, Fuchs BM, Scanlan DJ, Burkill PH (2007) Microbial control of phosphate in the nutrient-depleted North Atlantic subtropical gyre. Environ Microbiol 9:2079-2089. doi:10.1111/j.1462-2920. 2007.01324.x 